\title{
Diferensiasi Produk Sebagai Strategi Komunikasi Pemasaran pada Lahan Pemakaman Firdaus Memorial Park
}

\author{
Entus Nuryana Ahmad \\ Sekolah Tinggi Ilmu Komunikasi (STIKOM) Yogyakarta \\ entusahmad@gmail.com
}

\begin{abstract}
Products that have a different can be used as a hallmark of a company. Product differentiation is part of the marketing communication strategy. Competitive advantage raised through various creations of differentiation will be the best strategy to shape consumer perceptions of the uniqueness that is highlighted. This study aims to determine the product differentiation as communication strategy by Firdaus Memorial Park in West Bandung, West Java. Method used in this study is a descriptive method with a qualitative approach, which tries to describe a situation or event and does not try to find or explain relationships, does not test hypotheses or make predictions. Firdaus Memorial Park is considered consistent by claiming its position as a cemetery that is different from commercial cemeteries by marketing communication strategy. Product differentiation based on Islamic law seems to position Firdaus Memorial Park as the first Muslim cemetery in Indonesia to use the waqf concept. Then it was strengthened by several productive waqf products which were run for the benefit of Muslims.
\end{abstract}

Keywords: Funeral, Product Differentiation, Marketing Communication, Waqf

Abstrak: Produk yang memiliki diferensiasi unik dan berbeda dapat dijadikan sebagai ciri khas dari suatu perusahaan. Diferensiasi produk merupakan bagian dari strategi komunikasi pemasaran. Keunggulan bersaing dimunculkan melalui berbagai penciptaan diferensiasi akan menjadi strategi terbaik untuk membentuk persepsi konsumen atas keunikan yang ditonjolkan. Penelitian ini bertujuan untuk mengetahui diferensiasi produk sebagai strategi komunikasi pemasaran yang dibangun oleh Firdaus Memorial Park di Kabupaten Bandung Barat, Jawa Barat. Metode yang digunakan dalam penelitian ini adalah metode deskriptif dengan pendekatan kualitatif, yang mencoba memaparkan situasi atau peristiwa dan tidak mencoba untuk mencari atau menjelaskan hubungan, tidak menguji hipotesis atau membuat prediksi. Hasil penelitian menunjukkan bahwa Firdaus Memorial Park dinilai konsisten dengan mengklaim posisinya sebagai pemakaman yang berbeda dari pemakaman komersial dari perspektif komunikasi pemasaran. Diferensiasi produk yang dibangun berdasarkan syariat islam rupanya memposisikan Firdaus Memorial Park sebagai pemakaman muslim pertama di Indonesia yang menggunakan konsep wakaf. Kemudian diperkuat dengan beberapa produk wakaf produktif yang dijalankan demi kemaslahatan umat muslim.

Kata Kunci: Pemakaman, Diferensiasi Produk, Komunikasi Pemasaran, Wakaf

\section{Pendahuluan}

Tingginya angka kelahiran disertai arus urbanisasi yang besar menyebabkan perkembangan jumlah penduduk di perkotaan meningkat secara tajam. Akibatnya, banyak lahan di perkotaan berubah menjadi area pemukiman, perkantoran, supermarket, mall, apartement serta daerah industri lainnya sehingga menyebabkan ruang terbuka hijau menjadi turun secara signifikan. Undang-undang no. 26 Tahun 2007 tentang penataan ruang, perencanaan tata ruang wilayah kota harus memuat rencana penyediaan dan pemanfaatan 
ruang terbuka hijau dengan luas minimal 30\% dari luas wilayah kota yaitu terdiri dari 20\% ruang terbuka hijau publik dan $10 \%$ terdiri dari ruang terbuka hijau privat.

Ruang terbuka hijau sendiri dapat berupa taman kota, jalur hijau dan tempat pemakaman umum. Pemakaman merupakan alternatif untuk menciptakan lahan terbuka hijau. Ruang terbuka hijau berupa pemakaman umum, sebagaimana pemanfaatan utamanya sebagai kuburan dengan kegiatan didalamnya seperti berziarah, diharapkan masih memiliki fungsi lain. Ketersediaan lahan untuk pemakaman berbanding terbalik dengan laju pertumbuhan dan pembangunan yang ada di daerah perkotaan. Artinya, penduduk kota yang semakin hari semakin bertambah tidak dibarengi dengan ketersediaan lahan yang cukup untuk pemakaman. Sehingga dibutuhkan lahan pemakaman yang cukup dan tenaga profesional dari penyedia jasa pemakaman untuk mengurus jenazah.

Beberapa tahun belakangan ini jasa pemakaman dianggap sebagai lahan baru untuk melakukan investasi. Hal ini dikarenakan media informasi yang terus-menerus memberikan informasi mengenai image baru pemakaman. Di samping itu, ternyata memiliki pangsa pasar yang cukup potensial. Maka tak heran saat ini orang-orang mulai tertarik untuk memiliki lahan pemakaman sebagai bentuk investasi di masa akhir hayatnya. Karena pemakaman dianggap suatu lahan investasi, cukup banyak perusahaan mulai melirik bisnis jasa pemakaman ini sebagai kegiatan bisnis mereka. Pada dasarnya beberapa perusahaan pemakaman yang bermunculan berlomba memenangkan persaingan bisnis melalui strategi komunikasi pemasaran dan keunggulannya masing-masing.

Keunggulan bersaing merupakan strategi komunikasi pemasaran yang menawarkan nilai lebih kepada konsumen, baik melalui harga yang lebih rendah atau dengan menyediakan lebih banyak manfaat yang mendukung pendapatan harga lebih mahal (Kotler \& Amstrong, 2014). Keunggulan bersaing merupakan posisi unik atau sebagai kekuatan untuk mengalahkan para persaingan dengan menciptakan suatu produk yang spesial dan lebih menguntungkan dibandingkan dengan para pesaing (Wulandari \& Murniawaty, 2019). Pada dasarnya keunggulan bersaing tumbuh dari nilai dan manfaat dari sebuah produk atau jasa yang dibuat oleh perusahaan. Menurut Kotler, keunggulan bersaing sebuah perusahaan salah satunya dengan perbedaan (differentition) tawaran perusahaan yang akan memberikan nilai lebih kepada konsumen ketimbang yang dibawakan pesaing (Syauqi, 2018). Produk yang memiliki diferensiasi unik dan berbeda dapat dijadikan sebagai ciri khas dari suatu perusahaan. Dalam hal ini, keunggulan yang berupa posisi superioritas dalam sebuah industri atau pasar sehingga perusahaan dapat meningkatkan kinerja perusahaan karena keunggulan bersaing dapat dicapai dari berbagai kompetensi yang dimiliki dan ditingkatkan melalui asset-asset strategis bawaaan khas perusahaan (Afiyati, 2019). Keunggulan bersaing akan muncul ketika menyampaikan nilai pelanggan yang lebih besar. Aspek-aspek nilai pelanggan tersebut bisa berupa harga yang lebih murah dan manfaat yang didapat lebih banyak. Oleh karena itu keunggulan bersaing dimunculkan melalui berbagai penciptaan diferensiasi akan menjadi strategi komunikasi pemasaran terbaik untuk membentuk persepsi kepuasaan konsumen akan keunikan yang ditonjolkan. Keunggulan bersaing (competitive advantage) sebagai suatu keadaan dimana ketika sebuah perusahaan dapat melakukan sesuatu dan perusahaan lainnya tidak dapat, atau memiliki sesuatu yang diinginkan pesaingnya (David, 2017). 
Diferensiasi produk dalam komunikasi pemasaran dinilai dapat menciptakan sesuatu yang dapat diterima sebagai suatu yang unik pada tingkat pasar konsumen. Dalam komunikasi pemasaran, diferensiasi merupakan suatu upaya untuk menciptakan perbedaan antara produk pesaing sehingga memiliki nilai terbaik di benak konsumen (Zahara et al., 2020). Strategi diferensiasi adalah suatu tindakan dalam merancang atau membuat satu set perbedaan yang memiliki arti untuk membedakan penawaran perusahaan dari penawaran pesaing (Fadilla, 2015). Indikator dari diferensiasi produk terdiri dari bentuk, fitur, kualitas, kinerja, kesesuaian, keandalan dan gaya. Pentingnya diferensiasi karena banyak konsumen atau pun pelanggan dari sebuah produk memiliki dua alas an untuk dapat membeli produk tersebut. Alasan pertama, para konsumen akan memilih barang atau jasa jika memiliki kualitas yang lebih baik. Alasan kedua, konsumen akan memilih barang atau jasa jika memiliki harga yang murah (Assauri, 2013).

Kualitas bisa dikatakan dari bagaimana produk itu disesuaikan dengan baik dan sesuai dengan yang digunakan, dan juga dipercaya selama berakhirnya waktu. Suatu penentu terpenting pada kesuksesan produk baru dan keuntungan adalah pada mutu produk (Perlusz, Gattiker, Pedersen, 2013). Keandalan, mudah diperbaiki, gaya dan rancangan. Pemilihan produk di antara banyaknya tawaran yang ada di pasar selalu didasarkan pada adanya perbedaan, baik secara implisit maupun eksplisit. Keunggulan bersaing adalah kemampuan suatu perusahaan untuk meraih keuntungan ekonomis di atas laba yang mampu diraih oleh pesaing di pasar dalam industri yang sama. Perusahaan yang memiliki keunggulan kompetitif senantiasa memiliki kemampuan dalam memahami perubahan struktur pasar dan mampu memilih strategi pemasaran yang efektif (Porter, 2012).

Beberapa tahun terakhir brand pemakaman di Indonesia bermunculan dengan keunggulannya masing-masing. Pemakaman San Diego Hills misalnya yang terkenal dengan makam komersial yang mewah. Pemakaman tersebut dianggap mewah karena harga yang dipatok untuk sebuah makam pun cukup fantastis. Kompleks pemakaman tersebut menawarkan fasilitas seperti gazebo, tempat ibadah, restoran, pemandangan alam, jogging track, hingga pelayanan keamanan 24 jam. Wajah pemakaman pun diubah sedemikian rupa menjadi pemakaman yang jauh dari kesan menyeramkan. Bila dicermati, fenomena kemunculan pemakaman mewah sebenarnya merupakan hal yang wajar untuk saat ini. Para pakar sosial budaya sebelumnya telah memprediksi hal tersebut sebagai budaya konsumen atau consumer culture. Dalam arti lain sebuah budaya yang dibentuk dengan kapitalisme dimana pergerakan ekonomi berpusat pada barang atau jasa yang berpotensi besar menarik konsumen. Gaya hidup dan penggunaan barang maupun jasa untuk mencapai kebahagiaan dan kepuasan konsumen merupakan bagian terpenting dalam budaya konsumen (Lury, 2011). Selain itu budaya konsumen sangat menekankan aspek kebahagiaan, dalam beberapa hal juga gengsi, yang didapatkan dari materi, maka tidak heran bila banyak orang menghabiskan uangnya dalam jumlah besar hanya untuk mendapatkan kebahagiaan semata. Dalam hal ini budaya konsumen, dalam ranah akademik, sangat menekankan aspek psikologi dan sosiologi. Dalam konteks makam mewah, ada kebanggaan dan kepuasan tersendiri bila masyarakat, utamanya kelas menengah ke atas, bisa mempunyai tempat tinggal terakhir yang elegan dan mewah (Garadian, 2015). 
Polemik makam mewah di Indonesia pertama kali muncul ketika San Diego Hills, yang berlokasi di Karawang dan didirikan pada tahun 2010, mendapatkan reaksi penentangan dari MUI. Bagi MUI, status pemakaman San Diego Hills yang melakukan jual-beli dan bisnis lahan makam hukumnya adalah haram karena prinsip yang bekerja dalam akad yang dilakukan pengelola makam tersebut mengandung unsur tabdzir dan israf, baik dari segi luas, harga, fasilitas, maupun nilai bangunan. Berbagai media memberitakan tentang eksistensi makam komersial atau makam mewah sempat menjadi viral sejak Desember 2013 hingga akhir Februari 2014. Sejumlah media menyoroti, bentuk kuburan yang elegan dan besar, tinggi kuburan yang tidak sesuai dengan syariah, biaya mahal dari sebuah makam yang mana biaya per kavlingnya bahkan melebihi harga rumah penduduk kelas bawah hingga fatwa haram MUI terhadap keberadaan makam komersial tersebut (Garadian, 2015).

Saat situasi yang seperti itu, lahirlah Firdaus Memorial Park. Wakaf Pro 99 merupakan lembaga pengelola Firdaus Memorial Park yang memiliki perbedaan dari pemakaman kebanyakan. Firdaus Memorial Park dikelola dengan konsep wakaf, bukan bisnis jual beli atau komersil. Undang-undang nomor 41 tahun 2004, mengartikan wakaf sebagai perbuatan wakif untuk memisahkan atau menyerahkan sebagian harta benda miliknya untuk dimanfaatkan selamanya atau untuk jangka waktu tertentusesuai dengan kepentingannya guna keperluan ibadah dan/atau kesejahteraan umum. Sehingga akad yang digunakan pun bukan jual beli, namun konsep akad wakaf. Berbeda dengan pemakaman lainnya yang menggunakan konsep jual beli. Firdaus Memorial Park tidak hanya memiliki fasilitas yang nyaman serta jauh dari kesan menyeramkan. Namun lebih dari itu Firdaus Memorial Park memiliki konsep pemakaman syar'i, sebagaimana rekomendasi yang telah diberikan oleh Majelis Ulama Indonesia. Firdaus Memorial Park menjadikan konsep wakaf ini sebagai strategi diferensiasi mereka.

Strategi diferensiasi adalah suatu strategi yang dapat memelihara loyalitas pelanggan agar mendapat nilai lebih dibandingkan dengan produk lainnya. Memberi penawaran produk yang berbeda dinilai akan mampu mempengaruhi pilihan konsumen. Menurut Aaker strategi diferensiasi yang baik harus memenuhi tiga syarat, yakni: menghasilkan nilai pelanggan, memunculkan persepsi yang bernilai khas dan baik dan tampil sebagai wujud berbeda yang sulit untuk ditiru (Dahlan, 2018).

Setiap perusahaan tentunya memiliki strategi tersendiri untuk mengkomunikasikan produk maupun jasanya. Firdaus Memorial Park memiliki diferensiasi yang signifikan dengan tempat pemakaman lainnya. Hal ini sengaja dibuat agar menjadi nilai pembeda dari brand pemakaman lainnya. Atas dasar pemikiran tersebut, maka penulis tertarik untuk melakukan penelitian dengan judul Diferensiasi Produk Sebagai Strategi Komunikasi Pemasaran pada Lahan Pemakaman Firdaus Memorial Park.

\section{Metode}

Penelitian ini menggunakan metode deskriptif kualitatif. Penelitian kualitatif adalah "prosedur penelitian yang menghasilkan data deskriptif berupa kata-kata tertulis atau lisan dari orang-orang dan prilaku yang dapat diamati" (Moleong, 2012). Penelitian kualitatif bertumpu pada latar belakang alamiah secara holistik, memposisikan manusia sebagai alat penelitian, melakukan analisis data secara induktif, lebih mementingkan proses daripada hasil 
penelitian yang dilakukan disepakati oleh peneliti dan subjek penelitian Dalam penelitian kualitatif yang menjadi instrumen atau alat penelitian adalah penelitian itu sendiri. Oleh karena itu, peneliti sebagai instrumen juga harus divalidasi seberapa jauh peneliti kualitatif siap melakukan penelitian yang selanjutnya terjun ke lapangan (Sugiyono., 2012). Metode deskriptif dipilih karena penelitian yang dilakukan adalah berkaitan dengan peristiwaperistiwa yang sedang berlangsung dan berkenaan dengan kondisi masa sekarang.

Menurut Travels dalam (Hikmat, 2011) tujuan utama menggunakan metode ini untuk menggambarkan sifat suatu keadaan yang sementara berjalan pada saat penelitian dilakukan dan memeriksa sebab-sebab dari suatu gejala tertentu. Metode deskrptif adalah satu metode dalam meneliti status kelompok manusia, suatu subjek, suatu set kondisi, suatu sistem pemikiran atau pun kelas peristiwa pada masa sekarang. Tujuan dari penelitian ini yakni menggambarkan tentang strategi komunikasi pemasaran Firdaus Memorial Park I di Kawasan Cikalong Wetan, Kabupaten Bandung Barat dalam membangun diferensiasi dengan pelayanan jasa pemakaman lainnya.

Sumber data merupakan informasi yang diperoleh dari data penelitian (Sujarweni, 2014). Informasi dari narasumber, informan, teman, partisipan, guru dalam penelitian disebut sebagai sumber data (Ibrahim, 2018). Informan yang tepat menjadi kunci penentu dari penelitian. Informan yang dipilih sebagai sumber data utama dalam sebuah penelitian harus paham betul mengenai permasalahan, mempunyai dukungan data yang cukup, tahu seluk beluk Firdaus Memorial Park. Diantaranya adalah pengelola lembaga sosial Wakaf Pro 99 yang dinaungi oleh Yayasan Sinergi Foundation yang merupakan pemilik Firdaus Memorial park ini.

Teknik pengumpulan data yang digunakan dalam penelitian ini adalah wawancara mendalam, observasi dan dokumentasi. Teknik wawancara mendalam (indepth interview) merupakan teknik menggali informasi dari narasumber dengan melakukan wawancara secara langsung atau face to face. Wawancara adalah proses memperoleh keterangan untuk tujuan penelitian dengan cara tanya jawab, sambil bertatap muka antara si pewawancara dengan responden dengan menggunakan alat yang dinamakan panduan wawancara. Indepth interview merupakan suatu teknik pengumpulan data atau informasi secara bertatap muka langsung dengan sumber informasi dengan tujuan untuk mendapatkan data secara aktual dan mendalam. Wawancara mendalam (indepth interview) dilakukan secara intensif dengan frekuensi tinggi (berulang-ulang) (Kriyantono, 2008). Data primer diperoleh dengan melakukan wawancara mendalam dengan teknik semi terstruktur. Berdasarkan jenis data yang dibutuhkan, dalam penelitian ini, peneliti menjadikan partisipan yang dijadikan sumber data yang bentuknya dapat berupa dokumen-dokumen, manusia, benda dan sebagainya. Cara ini dinilai bisa menghasilkan data atau informasi yang lengkap dan akurat (Ardianto, 2010). Teknisnya yakni peneliti dan informan melakukan Tanya jawab secara langsung sehingga data atau pun informasi yang dibutuhkan bisa didapat secara langsung. Adapun informan dalam penelitian ini adalah Asep Irawan sebagai Direktur Wakaf Pro 99.

Jenis wawancara yang digunakan adalah wawancara semi terstruktur pelaksanaan wawancara ini lebih bebas jika dibandingkan dengan wawancara terstruktur. Teknik yang digunakan dalam wawancara semi terstruktur tujuannya yaitu agar wawancara tidak berlangsung secara kaku, sehingga mampu menggali data secara mendalam. Selain itu 
tujuannya adalah untuk menentukan permasalahan secara lebih terbuka, dimana pihak yang diwawancarai diminta pendapat dan ide-idenya. Peneliti beranggapan dengan teknik wawancara semi terstruktur, pertanyaan peneliti dapat berkembang sesuai dengan situasi yang ada, namun tetap terarah pada topik pembahasan peneliti yang terkait. Peneliti tidak menggunakan teknik wawancara yang lain karena dikhawatirkan akan sulit untuk mencapai titik kematangan informasi yang digali dari informan.

Observasi merupakan teknik untuk mengumpulkan data kedua yang dilakukan oleh peneliti. Observasi bisa dikatakan sebagai bahan utama untuk menggambarkan serta menjelaskan fenomena yang ada dalam penelitian. Interaksi antara subjek yang sedang diteliti merupakan hal yang mesti digambarkan dengan jelas. Observasi non partisipan digunakan dalam penelitian ini karena peneliti tidak terjun langsung di dalam perusahaan tersebut melainkan hanya menjadi pengamat saja. Artinya, peneliti hanya mengamati fokus penelitian dengan tidak terjun langsung dengan apa yang diteliti (Ardianto, 2010).

Teknik pengumpulan data yang ketiga ialah dokumentasi. Bentuk pengumpulan data dari teknik dokumentasi ini merupakan data tambahan meliputi buku, tulisan, jurnal, artikel, koran, majalah dan dokumen lain yang sifatnya tercetak maupun online.

Teknik analisis data yang dilakukan peneliti mencakup penyajian data, reduksi data kemudian penarikan kesimpulan. Reduksi data yaitu proses pemilahan, pemfokusan perhatian terhadap penyederhanaan, dan transformasi hasil data yang timbul dari hasil tulisan-tulisan di lapangan. Setelah peneliti memperoleh data dari lapangan, terlebih dahulu diuji kelayakannya dengan memilah data yang benar-benar diperlukan dalam penelitian ini. Dalam proses mereduksi data, peneliti melakukan pengelompokan informasi dari setiap informan berdasarkan pokok permasalahan masing masing. Proses penyajian data, peneliti membentuk tabel dari hasil penelitian yang diperoleh untuk menerangkan hasil penelitian secara lebih ringan dan mudah dipahami. Analisa hasil penelitian ini, peneliti melakukan penyimpulan dengan cara menjelaskan setiap bagian-bagian penting dari setiap pembahasan yang ditemukan di lapangan.

\section{Hasil dan Pembahasan}

Fenomena pemakaman mewah pun menuai beragam persepsi dari masyarakat maupun lembaga terkait tentang jual beli tanah makam. Pada tahun 2013 Firdaus Memorial Park muncul dengan konsep pemakaman berbasis wakaf. Firdaus Memorial Park lahir di bawah lembaga sosial Wakaf Pro 99 yang dinaungi oleh Yayasan Sinergi Foundation. Seiring dengan perkembangan zaman, berbagai jenis bisnis baru mulai bermunculan. Mulai dari bisnis kuliner dengan konsep aneh, sampai bisnis yang berbau 'kematian', seperti pemakaman dan rumah duka. Lahan pemakaman Firdaus Memorial Park ini memiliki keunggulan bersaing dari sisi strategi komunikasi pemasaran.

Beberapa brand pemakaman mewah bermunculan dengan menawaarkan harga kavling sampai ratusan juta rupiah. Harga yang dinilai fantastis dibeberapa brand pemakaman rupanya masih belum termasuk pemandian jenazah, pembungkusan kafan, sewa sound system, tenda, dan lainnya. Pemakaman mewah juga menawarkan banyak fasilitas seperti jogging track, kolam renang, kapel pernikahan atau masjid, dan lain-lainnya. Namun beberapa dari pemakaman tersebut sifatnya profitable. Berbeda jauh dengan Firdaus 
Memorial Park yang bertujuan untuk membantu para kaum dhuafa yang kesulitan dalam membiayai proses pemakaman. Produk yang ditawarkan meliputi (ambulance dan lahan pemakaman), jasa (pemulasaraan jenazah), orang (tim peulasaraan jenazah yang profesional). Firdaus Memorial Park memiliki banyak perbedaan dengan Tempat Pemakaman Umum lain. Hal ini sengaja dikonsep oleh Wakaf Pro 99 yang menemukan beberapa fakta tentang Tempat Pemakaman Umum, khususnya di Kota Bandung terkesan meyeramkan, tidak nyaman dan kotor. Maka dari itu sebagai nilai pembeda Firdaus Memorial Park yang pertama adalah konsep Asri, Nyaman, Ramah Lingkungan dan Sesuai Syariah. Direktur Wakaf Pro 99 menyatakan bahwa :

"Konsep kompleks pemakaman sesuai tagline Asri yang dimaksud ialah indah dan enak ketika dilihat mata. Konsep pemakaman Firdaus Memorial Park sebetulnya ingin menjadi pemakaman yang lebih mirip taman bukan miip kuburan. Nyaman artinya menciptakan ketenangan siapa saja yang datang. Pada dasarnya pemakaman itu harus membuat khusyu dan nyaman siapa pun yang berziarah atau yang mengantarkan jenazah. Oleh karena itu kawasan pemakaman ini harus dijauhkan dari banyaknya pengemis dan segala hal yang mengganggu. Ramah Lingkungan artinya ramah terhadap alam dan harus bebas dari bangunan atau tembok yang akan menghambat resapan air. Terakhir, Sesuai Syariah artinya sesuai dengan teladan Nabi. termasuk larangan membangun di atasnya, mencegah peziarah untuk melakukan ibadah di atasnya, dan mencegah anak-anak atau siapa pun yang mengutak-atik makam".

Keempat tagline di atas menjadi upaya Firdaus Memorial Park untuk memunculkan stigma baru mengenai pemakaman. Dalam konteks diferensiasi konsep syari'ah yang digunakan oleh Firdaus Memorial Park memunculkan persepsi yang bernilai khas dan baik. Kompleks pemakaman dibuat untuk mengikis stigma masyarakat yang menganggap pemakaman merupakan tempat yang menyeramkan. Beberapa pemakaman elite memiliki konsep yang sama, bersih, tertata, nyaman dan tidak menyeramkan, bahkan harus lebih mirip dengan taman daripada kuburan. Namun satu hal yang membedakan Firdaus Memorial Park dengan pemakaman lainnya terdapat pada konsep "Sesuai Syari'ah". Beberapa brand pemakaman dapat dikatakan tidak sesuai syari'ah karena menyatukan makam muslim dan non muslim dalam satu komplek pemakaman. Padahal jelas dalam agama islam Allah memuliakan orang beriman dan menghinakan orang kafir. Syariat islam melarang menguburkan orang kafir di pekuburan orang muslim, karena kuburan orang kafir adalah tempat yang akan diazab Allah, sedangkan kuburan orang muslim adalah tempat tercurahnya rahmat Allah (ampunan dosa). Maka itu, tidak selayaknya tempat rahmat dan azab berada dalam lokasi yang sama.

Beberapa pemakaman dianggap memiliki kesan yang sama oleh sebagian masyarakat diantaranya tanah pemakaman yang terlalu padat, pemakaman yang terkesan kotor, kondisi pemakaman yang cukup kumuh, sarana dan prasarana yang kurang memadai. Beberapa kesan tersebut membuat pemakaman memiliki image sebagai tempat yang angker. Pada dasarnya pemakaman bukan hanya berfungsi sebagai tempat peristirahatan terakhir bagi orang yang meninggal, tetapi juga menyediakan fasilitas, serta kualitas pelayanan yang baik. Firdaus 
Memorial Park ingin memunculkan kesan positif pada pemakaman agar keluarga yang ditinggalkan serta para peziarah lainnya merasakan kenyaman serta merasa bahwa pemakaman bukan suatu tempat yang menakutkan.

Nilai pembeda Firdaus Memorial Park yang kedua adalah penggunaan konsep wakaf. Awal mula kemunculan Firdaus Memorial Park terangkum dalam wawancara peneliti dengan Direktur Wakaf Pro 99:

"Jadi saya sekitar 2009 itu saya posisi suka tidur di kantor. Sekitar jam 8 malem ada yang mencet bel, lalu saya turun ke bawah lalu ada sepasang suami istri yang bawa anak yang waktu itu memang nafasnya itu udah terputus putus, sudah terbatas gitu ya. Kemudian waktu itu saya langsung bawa ke UGD RSHS. Belum lama di UGD ternyata anak ini tidak tertolong. Lalu saya bawa pulang ke rumahnya di Kopo Citarip yang rumahnya tepat di kontrakan belakang perumahan. Lalu saya ngobrol dengan insting saya aja dengan DKM, RT, RW nanyain tentang proses pemakaman anak ini gimana. Ternyata karena anak ini ngontrak gitu dan biaya pemakaman di TPU Kota Bandung yang ada itu membutuhkan dana kurang lebih 600 ribu. Uang 600 ribu untuk seorang pedagang kecil itu kan modal hidup mereka. 600 ribu itu menjadi masa depan anak anaknya, 600 ribu itu adalah kehidupan mereka. Naaaah dari situ saya diskusi dengan dan muncul ide membuat pemakaman muslim dengan konsep wakaf yang diberi nama "Taman Wakaf Pemakaman Muslim Firdaus Memorial Park ".

Konsep wakaf yang dipakai oleh Firdaus Memorial Park telah sesuai dengan lembaga yang menaunginya. Selain itu, penggunaan konsep wakaf oleh Firdaus Memorial Park dinilai sebagai konsep yang anti mainstream serta menjadi pembeda dari kompetitor. Sebagai lembaga sosial meamang sudah seharusnya Wakaf Pro 99 membuat program yang bisa meringankan beban kaum dhuafa yang kesulitan mencari lahan pemakaman dan biaya pemakaman yang kian hari kian naik. Wakaf Pro 99 berkomitmen menjadikan wakaf sebagai jalan untuk menyiarkan Islam. Firdaus Memorial park menggunakan konsep wakaf produktif.

Nilai pembeda Firdaus Memorial Park yang ketiga ialah kepemilikan surat rekomendasi syar'i dari Majelis Ulama Indonesia. Pembangunan kuburan mewah yang sifatnya jual beli pun menjadi soroatan Majelis Ulama Indonesia. Pada tahun 2014 Majelis Ulama Indonesia mengeluarkan fatwa haram mengenai jual beli tanah untuk kuburan dan bisnis lahan kuburan mewah. Salah satu poin pentingnya menyatakan jual beli dan bisnis makam mewah terdapat unsur tabdzir dan israf hukumnya haram. Tabdzir ialah membelanjakan harta untuk sesuatu yang tidak bermanfaat yang bisa memunculkan kesiasiaan serta tidak sesuai dengan aturan agama. Sedangkan Israf ialah perilaku belebihan dalam konteks ini yakni pemakaman yang berlebihan.

Adanya fatwa haram dari Majelis Ulama Indonesia tentang haramnya jual beli lahan pemakaman, memotivasi Wakaf Pro 99 untuk meminta Majelis Ulama Indonesia mengkaji ulang Firdaus Memorial Park. Setelah dilakukan pengkajian, Majelis Ulama Indonesia menetapkan Firdaus Memorial Park jauh dari unsur bisnis jual beli makam. Mulai dari akad wakaf sampai proses pelaksanaan pemakamannya sesuai dengan konsep syariah. Hingga 
akhirnya Majelis Ulama Indonesia mengeluarkan surat rekomendasi syar'i pada Firdaus Memorial Park. Sejalan dengan hal tersebut, Direktur Wakaf Pro 99 mengatakan bahwa:

"Mindset wakaf di masyarakat perlu berubah, maka dari itu Wakaf Pro 99 mengajak masyarakat untuk mengubah cara berfikir tentang wakaf. Wakaf bukan sekadar sosial saja melainkan harus produktif. Karena wakaf yang produktif nilai manfaatnya berlipat ganda, tetapi prinsipnya tetap terjaga. Wakaf produktif nampaknya masih menjadi barang baru di kalangan masyarakat. Saat diaplikasikan kepada masyarakat butuh sosialisasi agar paham bahwasanya ternyata wakaf berbentuk uang yang diusahakan pada berbagai bidang itu bisa dalam agama. Beberapa wakaf produktif yang dikelola oleh Wakaf Pro 99 sudah mulai berjalan cukup banyak. Rumah Makan Ampera Pasteur, toko fashion muslim, Rumah Bersalin Cuma-Cuma, Baso cuanki Serayu (di area Gedung Wakaf Pro 99), Kopi Haii serta aset-aset lokal lainnya merupakan hasil optimalisasi pengelolaan dana wakaf".

Nilai pembeda Firdaus Memorial Park yang keempat yakni istilah penggantian istilah "harga" menjadi "nilai wakaf". Wakaf Pro 99 menegaskan kembali bahwa Firdaus Memorial Park bukan berbasis jual beli tanah. Konsep wakaf produktif hanya menghimpun dana wakaf dari masyarakat muslim yang mampu, sehingga sama sekali jauh dari unsur bisnis. Nilai wakaf yang ditawarkan relatif cukup rendah yakni Rp. $15.000 .000+$ infaq $10 \%$. Artinya pewakif hanya mengeluarkan uang sejumlah Rp. 16.500.000 saja dengan benefit yang didapat diantaranya 2 kavling pemakaman untuk keluarga wakif, 2 kavling pemakaman untuk keluarga dhuafa. Hal ini berarti wakif tidak sekedar "membeli" barang atau jasa, tetapi lebih pada membeli manfaat dan nilai dari sesuatu yang ditawarkan. Aspek-aspek nilai pelanggan yang dibangun oleh Firdaus Memorial Park berupa harga yang lebih murah dan manfaat yang didapat lebih banyak dibanding para pesaingnya. Ini merupakan keunggulan bersaing dimunculkan Firdaus Memorial Park melalui berbagai penciptaan diferensiasi dari segi harga. Hal ini akan menjadi strategi komunikasi pemasaran terbaik untuk membentuk persepsi kepuasaan konsumen akan keunikan yang ditonjolkan. Direktur Wakaf Pro 99 mengatakan bahwa:

"Dari awal tujuan kita mendirikan Firdaus Memorial Park ialah untuk membantu kalangan dhuafa yang kurang mampu membayar biaya pemakaman. Maka dari itu nilai wakaf yang kami tetapkan ditujukan pada orang-orang yang mampu dan ingin membantu para kaum dhuafa yang kesulitan membayar biaya pemakaman. Sebelum kita menentukan harga, kita survei ke San Diego Hills dan Al-Azhar dan TPU-TPU di kota Bandung, ditemukanlah fakta bahwa biaya pemakaman kurang lebih 700 sampai 2 juta waktu itu, kalo sekarang mungkin sekitar 3 jutaan. Sedangkan untuk pemakaman mewah seperti San Diego Hill dan Al-Azhar bernilai puluhan sampai ratusan juta rupiah bahkan ada yang sampai milyaran rupiah. Harga yang ditawarkan oleh perusahaan jasa pemakaman lain memang cukup besar terlebih bagi kaum dhuafa. Namun konsep berbasis wakaf produktif nonprofit yang dipakai dalam 
pemasaran Firdaus Memorial Park menjadi suatu solusi, berbeda dengan perusahaan pemakaman lain yang berbasis jual beli dan profit oriented”.

Firdaus Memorial Park mengambil posisi kontra terhadap eksistensi pemakaman mewah komersil. Menurut Direktur Wakaf Pro 99 pemakaman mewah yang konsepnya jual beli dinilai eksklusif untuk kalangan masyarakat menengah kelas atas saja. Hal ini ternyata menjadi solusi atas isu kedua yang mendasari kemunculan Firdaus Memorial Park. Konsep wakaf yang digunakan dapat memberikan kesempatan bagi orang yang sudah berwakaf untuk berkontribusi bagi kehidupan orang lain yang masih hidup. Ini berarti konteks kemaslahatan umat muslim merupakan sesuatu yang penting daripada keuntungan secara materi. Hadirnya banyak kompetitor mengakibatkan konsumen dihadapkan pada beberapa pilihan produk lain yang sejenis. Artinya, konsumen akan lebih banyak mendapat pilihan dalam menentukan pembelian produk sesuai dengan kebutuhannya. Fidaus Memorial Park berhasill mengatasi hal-hal tersebut dengan memberikan nilai kompetitif dibanding dengan para pesaingnya. Salah satu cara untuk bertahan dalam pasar yakni perusahaan harus memiliki nilai jual lebih dan nilai pembeda.

Hal ini jelas merupakan sebuah terobosan baru di masa sekarang, terlebih saat brand pemakaman lain mencari keuntungan penjualan makam, Firdaus Memorial Park lebih focus pada kemaslahatan muslim. Apalagi, Firdaus Memorial Park menawarkan konsep yang penulis istilahkan sebagai beli satu dapat banyak benefit. Dimana orang yang berwakaf makam secara otomatis juga memberikan kontribusi penyediaan makam bagi para dhuafa. Firdaus Memorial Park berusaha menghilangkan hal-hal tersebut yang dinilai mampu menimbulkan kesenjangan sosial antara masyarakat kurang mampu dengan para pembeli kavling-kavling pemakaman. Diferensiasi yang dilakukan Firdaus Memorial Park dinilai unik dan sulit ditiru oleh pesaing. Keunikan akan membuat suatu produk yang dihasilkan akan selalu diingat dan memiliki tempat di hati konsumennya. Sebagaimana hasil wawancara berikut ini:

"Pemakaman mewah yang bermunculan bisa mengakibatkan kesenjangan antara si miskin dan si kaya. Harga kavling pemakaman mewah komersil sangat mahal. Hal ini memicu berbagai polemik dimasyrakat seolah-olah orang miskin dilarang "mati". Kalau konsepnya wakaf, semuanya akan terbantu baik si "kaya” maupun si "miskin". Selain itu para agniyya memiliki kesempatan untuk memperoleh pahala yang mengalir sampai akhirat karena wakaf merupakan bentuk dari amal jariyah yang pahalanya akan mengalir terus".

Firdaus Memorial Park menjadi solusi atas permasalahan padatnya ruang terbuka hijau di perkotaan dan biaya pemakaman yang tidak murah. Solusi ini dibuat untuk para kaum dhuafa yang kesulitan memperoleh pemakaman yang layak dan keterbatasan biaya untuk memakamkan keluarga atau sanak saudaranya. Hal ini yang menjadi dasar Firdaus Memorial Park tidak menggunakan konsep jual-beli. Terdapat perbedaan dari segi target pasar Firdaus Memorial Park yakni para agniyya (orang muslim mampu) yang ingin berwakaf untuk lahan pemakaman keluarganya serta turut membantu kalangan dhuafa. Artinya dalam hal ini ada 
target untuk menghimpun dana dan target penerima manfaat dari orang yang berwakaf. Hal tersebut merupakan strategi Firdaus Memorial Park untuk menghasilkan nilai pelanggan. Nilai pelanggan akan terbentuk jika mereka telah menggunakan produk yang dipilihnya. Nilai bisa di rasakan oleh para pelanggan jika sudah menggunakan produknya karena nilai merupakan pengalaman yang dirasakan pelanggan. Kesan emosi yang dirasakan oleh pewakif merupakan upaya Firdaus Memorial Park untuk menciptakan nilai pelanggan berupa kesan psikologi yang positif. Produk merupakan cerminan dari pemiliknya, oleh sebab itu pertimbangan dampak sosial merupakan faktor yang diperhatikan oleh setiap pelanggan. Karena setiap pelanggan ingin menunjukkan kesan positif dari orang lain terhadap dirinya. Selain itu Direktur Wakaf Pro 99 juga mengatakan bahwa:

"Firdaus Memorial Park berkonsep wakaf dan tidak jual kavling, maka kita sebagai pengelola belum bisa memplotting ini kavling milik A,B atau $C$ dan sebagainya. Karena yang lebih berhak atas kavling itu ada yang meinggal terlebih dulu. Artinya penggunaan kavling didasarkan pada “antrian” yang datang lebih dulu, tidak bisa memilih. Namun khusus untuk orang yang berwakaf jika salah satu keluarga meninggal dan dimakamkan di Firdaus Memorial Park, dipastikan lahan yang berdekatan dikosongkan untuk suami / istri / keluarga lain. Selain itu Insya Allah Kavling anak yatim piatu akan di bagi namun tidak membedakan bentuk fisik makam”.

Nilai pembeda Firdaus Memorial Park yang kelima adalah tidak adanya kesenjangan sosial seperti pemakaman komersial yang lainnya. Pengelola Firdaus Memorial Park berkomitmen siap melayani wakif maupun kaum dhuafa yang membutuhkan selama 24 jam. Keduanya akan memperoleh hak yang sama mulai dari prosesi memandikan, mengkafani, menyalatkan, hingga memakamkan, sampai penyediaan lahan pemakaman. Wakaf Pro 99 mengklaim sebagai lembaga wakaf yang profesional. Strategi diferensiasi adalah suatu tindakan dalam merancang atau membuat satu set perbedaan yang memiliki arti untuk membedakan penawaran perusahaan dari penawaran pesaing. Firdaus Memorial Park merupakan pemakaman yang benar-benar memperhaikan kondisi sosial di lingkungan masyarkat. Semua bentuk pemakaman di kompleks Firdaus Memorial Park disama ratakan sehingga tidak akan terjadi ketimpangan sosial antara pewakif dan dhuafa. Ini jelas membuktikan bahwa Firdaus Memorial Park berupaya tampil sebagi wujud pemakaman yang berbeda dan sulit ditiru oleh pesaing.

Nilai pembeda Firdaus Memorial Park yang keenam adalah penekanan konsep makam sesuai syariah. Firdaus Memorial Park mengikuti anjuran Rasul yang melarang mendirikan bangunan di atas kuburan dan mencegah para peziarah untuk melaksanakan ibadah lain yang tak sesuai dengan sunnah di komplek pemakaman. Selain itu, konsep pemakaman syariah yang digunakan oleh Firdaus Memorial Park mengadopsi konsep di Pemakaman Baqi atau pemakaman sahabat Nabi. Konsep pemakaman tersebut yakni 1 lubang bisa di isi berulang kali. Missal jenazah pertama dikebumikan sedalam 2 meter, jenazah kedua 1,6 meter dan jenazah terakhir 1,2 meter. Bahkan bisa lebih jika sudah melalui beberapa puluh tahun dan 
jenazah sudah menyatu dengan tanah, yang mana ini juga sebagai solusi agar lahan pemakaman tidak semakin meluas. Sebagaimana hasil wawancara berikut ini:

"Kebermanfaatan lahan untuk orang yang hidup itu harus lebih diutamakan dibanding yang meninggal. Firdaus Memorial Park mengadopsi Mekkah dan Madinah yang menerapkan konsep pemakaman "isi ulang” yang dalam sekian tahun jenazah mungkin sudah habis tinggal tulang belulang, diambil kemudian dipindahkan, karena intinya kan dia hanya mengembalikan jasad itu ketanah, setelah itu ngga ada urusan, alam ruh, alam kubur, segala macam kan bukan disana. Tatkala tanah itu sudah kosong, seharusnya kan bisa dimanfaatkan, saya pernah melihat temen-temen tim memindahkan jenazah yang dimakamkan tahun 70, tahun 80 gitu, digali ya ngga ada apa-apanya, kalau tanah ini dibiarkan kan sayang, mending dipakai lagi sama yang meninggal yang baru”.

Keterbatasan lahan pemakaman kadang memaksa tanah pemakaman digunakan lebih besar dari kapasitasnya. Firdaus Memorial Park memberikan solusi 1 liang lahat diisi 3 jenazah dengan jangka waktu tertentu. Namun khusus untuk wakif hak dua kavling dan penggunaan berulang (diisi ulang) hanya sebatas keluarga besar wakif dan atas izin keluarga wakif sendiri.

Nilai pembeda Firdaus Memorial Park yang ketujuh adalah pengelola yang dinilai profesional. Wakaf Pro 99 sadar akan kebutuhan sumber daya manusia yang handal dan profesional akan sangat membantu memperlancar syiar islam melalui wakaf. Namun mereka juga menyadari, produk yang ditawarkan oleh Wakaf Pro 99 erat kaitannya dengan keakhiratan (ukhrowi). Hal ini menjadikan sumber daya manusia yang ada di Wakaf Pro 99 memang harus benar-benar menyerahkan dirinya secara total demi tujuan syiar islam, khususnya dalam memahami konsep wakaf. Direktur Wakaf Pro 99 menegaskan kembali bahwa:

"Tugas kita dalam mencari karyawan memang sulit, apalagi awal-awal berdirinya Firdaus Memorial Park. Masih banyak orang yang mempermasalahkan gaji berapa? dapet apa aja? dan sebagainya yang bentuknya materi. Kita merupakan lembaga wakaf, gaji istilahnya lillahita'alla. Dari statement mereka yang seperti itu, kita udah ga cocok, kita butuh orang yang ikhlas membantu menyiarkan syariat islam, butuh orang yang benar benar total".

Pengelolaan Firdaus Memorial Park betul-betul diatur sedemikian rupa. Para professional dihadirkan dalam mengelola Firdaus Memorial Park. Selain para calon karyawan maupun karyawan perlu memahami ilmu agama yang kuat dan berdedikasi tinggi pada kemaslahatan umat muslim. Wakaf Pro 99 menginginkan karyawan yang tidak memperhitungkan seberapa banyak uang gaji yang akan didapat, melainkan seberapa kuat kita menyiarkan agama islam melalui wakaf. Sumber daya manusia yang ada di Firdaus Memorial Park termasuk orang-orang yang bededikasi tinggi dalam menjalankan syiar islam. Artinya, sumber daya manusia yang ada telah menerapkan konsep pengabdian, keikhlasan dan totalitas 
mereka dibuktikan dengan pelayanan cepat tanggap 24 jam. Orang-orang yang mengurus pemulasaraan jenazah, sopir ambulance, penggali kubur siap bekerja kapanpun demi pelayanan terbaik Firdaus Memorial Park. Hal ini menunjukkan profesionalisme mereka sebagai pekerja lillahita'aalaa. Direktur Wakaf Pro 99 menegaskan kembali bahwa:

"Tim pemulasaraan telah ada sejak FMP berdiri. Tenaga-tenaga terlatih dan professional dalam kepengurusan jenazah telah kami siapkan, demi mendukung dan menyempurnakan sistem yang dibangun FMP. Pemulasaraan tak hanya berbicara mengenai pengantaran jenazah saja. Jika keluarga memerlukan pendampingan, tim ini akan membantu dan mengedukasi terkait adab memandikan, mengkafani, dan menyolatkan. Tim pemulasaraan FMP siap melayani 24 jam bagi siapa saja keluarga dhuafa yang meninggal dunia dan kami gratiskan mereka”.

Kemunculan Firdaus Memorial Park menjawab permasalahan kaum dhuafa yang tidak mampu membiayai proses pemakaman. Firdaus Memorial Park siap melayani dari mulai prosesi memandikan, mengafani, menyalatkan, hingga memakamkan, sampai penyediaan lahan pemakaman. Pengelola Firdaus Memorial Park siap melayani 24 jam bila kaum dhuafa membutuhkan.

Nilai pembeda Firdaus Memorial Park yang ketujuh adalah penggunaan akad wakaf bukan jual beli. Seperti yang disampaikan oleh Direktur Wakaf Pro 99 sebagai berikut:

"Konsep kami yang berebeda dari pemakaman lain yang sifatnya komersil. Jikalau di pemakaman komersil kan istilah ada yang jual ada yang beli. Karena Firdaus Memorial Park ini dasarnya wakaf, bukan jual beli maka istilah transaksi nya pun berbeda. Firdaus Memorial Park mengimplementasika rukun-rukun wakaf, akadnya wakaf bukan jual beli seperi pemakaman komersil. Pertama, Wakif yang berarti orang yang berwakaf, dalam konteks penelitian ini ialah para agniyya (orang muslim yang aтрu). Kedua, Mauquf yang berarti harta atau pun benda yang diwakafkan, dalam konteks penelitian ini ialah nilai atau biaya wakaf. Ketiga, Mauquf Alaih yang berarti orang yang menerima manfaat dari wakif, dalam konteks penelitian ini ialah kaum dhuafa. Keempat, Shigah yang berarti ikrar wakaf, dalam konteks penelitian ini ialah pernyataan dari Wakif yang diucapkan secara lisan dan/atau tulisan kepada Nazhir (Firdaus Memorial Park) untuk mewakafkan uang miliknya”.

Sehingga jika dianalisis lagi dari perspektif komunikasi pemasaran, keunggulan bersaing Firdaus memorial Park merupakan strategi komunikasi pemasaran yang menawarkan nilai lebih kepada konsumen, baik melalui harga yang lebih rendah atau dengan menyediakan lebih banyak manfaat yang mendukung pendapatan harga lebih mahal (Kotler \& Amstrong, 2014). Keunggulan bersaing merupakan posisi unik atau sebagai kekuatan untuk mengalahkan para persaingan dengan menciptakan suatu produk yang spesial dan lebih menguntungkan dibandingkan dengan para pesaing (Wulandari \& Murniawaty, 2019). Konsep wakaf yang dipakai oleh Firdaus Memorial Park memberikan perbedaan yang signifikan dalam transaksinya. Tidak adanya istilah penjual dan pembeli seperti pemakaman komersial lainnya. 
Dalam konteks ini istilah yang dipakai ialah Wakif dan Nadzir (Pengelola Wakaf). Istilah dalam rukun wakaf yang digunakan menjadi bukti Firdaus Memorial Park bukanlah sebuah aktifitas jual-beli makam. Dalam hal ini, Firdaus Memorial Park mengklaim sebagai pemakaman berbasis wakaf pertama di Indonesia.

\section{Simpulan}

Berdasarkan pemaparan di atas, Firdaus Memorial Park dinilai konsisten dengan mengklaim posisinya sebagai lahan pemakaman yang berbeda dari pemakaman komersial dari perspektif strategi komunikasi pemasaran. Secara teoritis diferensiasi yang dibuat oleh Firdaus Memorial Park telah menghasilkan nilai pelanggan, memunculkan persepsi yang bernilai khas dan baik dan tampil sebagai wujud berbeda yang sulit untuk ditiru. Diferensiasi produk yang dibangun berdasarkan syariat islam rupanya memposisikan Firdaus Memorial Park sebagai pemakaman muslim pertama di Indonesia yang menggunakan konsep wakaf. Kemudian diperkuat dengan beberapa produk wakaf produktif yang dijalankan demi kemaslahatan umat muslim. Sehingga menjadikan FMP sebagai sebuah antitesis dari makammakam komersial yang ada. Konsep wakaf juga dinilai mampu membawa Firdaus Memorial Park sebagai pemakaman muslim yang memiliki kepedulian tinggi terhadap kaum dhuafa yang kesulitan lahan dan biaya pemakaman. Firdaus Memorial Park dinilai mampu menghapus ketimpangan sosial yang terjadi di pemakaman-pemakaman lain.

\section{Referensi}

Afiyati. (2019). Keunggulan Bersaing Sebagai Variabel Mediasi pada Pengaruh Strategi Diferensiasi dan Orientasi Pasar Terhadap Kinerja Bisnis UMKM di Kabupaten Purbalingga.

Ardianto, E. (2010). Metode Penelitian untuk Public Relations: Kuantitatif dan Kualitatif. Bandung: PT Simbiosa Rekatama.

Assauri, S. (2013). Manajemen Pemasaran. Jakarta: Rajawali Pers.

Dahlan, M. (2018). ANALISIS DAMPAK DIFERENSIASI PRODUK DAN CITRA MEREK TERHADAP KEPUTUSAN PEMBELIAN MIE SEDAAP PADA PT. TEKAD KARYA PUTRACABANG LUMAJANG.

David, Fred st R. R. dan David, Fore2017. Manajemen Strategik: Suatu Pendekatan Keunggulan Bersaing. Jakarta: Salemba Empat.

Fadilla, N. (2015). KEUNGGULAN BERSAING RITEL MODERN (Kasus Hypermart Mall SKA Pekanbaru). In Jom FISIP (Vol. 2, Issue 2).

Garadian, E. A. (2015). Polemik Makam Mewah: Firdaus Memorial Park Sebuah Terobosan dalam dunia Wakaf di abad-21. Al-Awqaf.

Hikmat, M. M. (2011). Metode Penelitian dalam Perspektif Ilmu Komunikasi dan Sastra. Graha Ilmu.

Ibrahim. (2018). Metodologi Penelitian Kualitatif. Bandung: Alfabeta

Kotler \& Amstrong. (2014). Principle Of Marketing 15th Edition. Pearson Prentice Hall. 
Kriyantono, R. (2008). Teknik Praktis Riset Komunikasi. Jakarta: Kencana Prenada Media Group.

Moleong, L. J. (2012). Metodologi Penelitian Kualitatif. Remaja Rosdakarya.

Perlusz, Gattiker, Pedersen. (2013). Talk To Your Internet Customers: What B2B And B2C Client Want To Know. Denmark: Department of Production., Aalborg Universiy.

Porter, M. (2012). Keunggulan Bersaing. Tim Penerjemah Binarupa Aksara.

Sugiyono. (2012). Metode Penelitian Kuantitatif Kualitatif dan $R \& B$. Alfabeta.

Suharsimi, A. (2008). Penelitian Tindakan Kelas. Bumi Aksara.

Sujarweni, W. (2014). Metodelogi Penelitian. Yogyakarta: Pustaka Baru Press.

Syauqi, A. (2018). DIFERENSIASI PRODUK SABYAN GAMBUS 2018. In Diferensiasi Produk Sabyan Gambus (Vol. 01, Issue 02). http://www.inteleksia.stidalhadid.ac.id/index.php/inteleksia/article/view/49

Wulandari, E., \& Murniawaty, I. (2019). PENINGKATAN KEUNGGULAN BERSAING MELALUI DIFERENSIASI PRODUK DAN DIFERENSIASI CITRA SERTA PENGARUHNYA TERHADAP KINERJA PEMASARAN IKM KOPI DI KABUPATEN TEMANGGUNG. Jurnal Manajemen Pemasaran, 13(2), 69-77. https://doi.org/10.9744/pemasaran.13.2.69-77

Zahara, A. P., Danial, R. D. M., \& Samsudin, A. (2020). Strategi Diferensiasi sebagai Upaya Mewujudkan Keunggulan Bersaing pada UKM Furniture. Ekuitas: Jurnal Pendidikan Ekonomi, 8(1), 20. https://doi.org/10.23887/ekuitas.v8i1.24410 